\title{
Causes of Attrition of Senior Level Employees: A Study on Selected Commercial Banks of Nepal
}

\author{
Jackson Subedi \\ MBA Student, Ace Institute of Management, Kathmandu, Nepal \\ Email: jacksonsubedi@gmail.com
}

\begin{abstract}
There are not many practical studies carried out to investigate the factors causing attrition in banking sector. The focus of this research is to find out the relationship of the factors towards attrition in the senior level position of commercial bank in Nepal. Attrition here is defined as the job switching behavior of the employees. The factors are broadly classified into working condition, nature of work, organizational philosophy, salary, and career progression. The research is based on the data collected from senior level employees of more than ten commercial banks out of thirty two. Structured questionnaire was used to receive the responses.
\end{abstract}

KEYWORDS: Attrition, Working Condition, Nature of Work, Career Progression, Organizational Philosophy.

\section{INTRODUCTION}

\section{General Background}

Human Resource (HR) managers are devising ways to retain talent. The banking sector in Nepal has certainly been lucrative area for employment in recent years where all the young minds want to be part of it. The increasing number of banks has provided plenty of employment to the youths. Lots of young talents are working in the banks and there are lots more who would like to join it.

One of the biggest issues currently faced by the banks is the remarkable rise in attrition rate. There could be some common attrition factors across sectors but every organization needs to know the specific reasons for attrition. The Nepalese economy is stagnant and uncertain although the banking sector is being somewhat vibrant and is still attracting more and more prospective employees. Since, there are plenty of banks opening branches and expanding its reach throughout the country, there is a demand in both the entry level positions and senior level positions. There are impatient staff seeking more secured and profitable career option leading to increase in attrition in Nepalese banking sector. In this study, attrition is defined as a job switching trend.

There are not many organizations that have specialized units for specialized work. HR management, customer relationship management (CRM), enterprise resources planning, etc are the departments that are not effectively used in business context of our country. There are plenty of organizations that has administrative department that looks after all the work that needs experts' decision to function properly. Global staffing firm "Kelly Services" expects attrition levels to rise to $22 \%$ in 2011 and feels that employees in customer management department, team 
management and the niche technical roles will grab the lion's share of increments next year. Mr. Goel of Global Hunt, however, views attrition as healthy and was of the view that " $A$ balanced attrition is healthy for an organization as it opens the avenue for fresh talent to come and create innovations which in turn can add lots of value to an organization. Low attrition will block fresh ideas and people will become too comfortable in their approach. But, high attrition may not give an opportunity to individual and organization to understand and to optimize strength. Quick job hoppers will have difficulty to get a good job as they will not be widely accepted for long term or larger roles" (The Economic Times: December 24, 2010).

Today, attrition is one of the major problems faced by various organizations across the globe. The condition is similar in our context too. There were plenty of jobswitches in the past years, side by side with the opening of new banks and/or branches. According to a recent survey conducted by All India Management Association (AIMA) on Chief Executive Officers (CEOs) and HR managers of different IT (Information Technology) organizations, it was found that attrition is the second important issue related to HR department. The impact of attrition has received considerable attention by senior management, HR professionals, and industrial psychologists. It has proven to be one of the most costly and seemingly intractable challenges confronting organizations. It is the big issue in banking industry of Nepal too and this study will highlight the major causes of attrition in the senior level position of banking sector and possible information for appropriate decision-making.

\section{Statement of Problem}

Commercial banks are seriously facing the issues of attrition and it would be beneficial for them to improve the statistics related to this issue. There are lots of switches in senior level positions where one gains experiences and moves to another bank creating vacant position for another banker to make a switch. There should be certain factors that are causing these switches. This research is an attempt to identify the causes of this attrition. There has not been any research of this kind allowing banks and financial institutions to develop strategies to improve the attrition rate in Nepal, however it is proved that employees who are satisfied with their jobs are more productive, creative and more likely to be retained by the company (Eskildsen and Dahlgaad, 2000; Kim, 2000; Kirby, 2000; Lee, 2000; Wagner, 2000).

Remuneration is considered as the topmost reason as to why senior level employees switch job from one bank to another but there has been no empirical evidence to support this statement. There is a gap in the research focusing on causes of attrition, especially in the banks of Nepal, which this study will try to fulfill. The identification of the causes of attrition will directly help the human resource department to devise a plan and strategies to improve the attrition rates. The trainings provided to the employees over the duration of their serving period is the investment of the company and there are lots of investments involved to make an employee fit for the work. This will be worthless when an employee does not serve the company for long term. Therefore, there has to be a plan which will help 
the company retain talents and lower the number of switches with the increase in company attrition rate.

Most of the commercial banks do not seem to have a proper HR management system that tracks the attrition rate of the company. There seems also not any effort to lower the attrition rate. Banks seem to have some training and development sessions, which are a part of regular exercise, but again this, may not be a case for all commercial banks. There are no pre-training and post-training evaluations, in order to record the progress of employees and to record the overall progress in the bank's performance.

Therefore, this research will attempt to find the answer the questions about the causes of attrition in the senior level positions of commercial banks. Specifically, it would focus on:

- Factors missing in the previous jobs of the employees;

- Factors that led these employees to switch banks; and

- Factors essential for the employee to remain in their current jobs.

\section{Research Objectives}

In this context, the objectives of this research would be:

- To assess the causes for attrition in senior level position of commercial bank;

- To analyze a conceptual framework based on the results of this study to understand the relation between attrition and factors affecting attrition;

- To recommend the commercial banks of Nepal to prepare strategies to lower the attrition rates based upon the findings of this research.

\section{Research Hypotheses}

To achieve the above objectives several hypotheses has been assumed as follows:

- There is no significant relationship between the working condition and attrition;

- There is no significant relationship between the nature of work and attrition;

- There is no significant relationship between the organizational philosophy and attrition;

- There is no significant relationship between the career progression and attrition;

- There is no significant relationship between the salary and attrition.

\section{Significance of the Study}

The present study will be beneficial to all the banks and financial institutions. There seems to be a lack of these types of study in Nepal. Most of the banks are trying their best to retain talents and stop them from switching jobs but unable to reduce the trend. They are mostly unaware of the causes of job switches and dropouts. This study will allow the banks to identify the causes of attrition. The banks will, thus, have knowledge about the different factors that are causing attrition in the senior level positions. After identification of the causes the HR managers can redesign their strategies and devise appropriate policies to decrease the attrition rates. The banks can also use the format of attrition report and self compute the attrition rate every year to trace whether their plans, policies, and strategies are being effective or not. The reduced attrition rate will allow banks to improve their 
staff retention rate, which will directly reflect in the financial performance of the banks.

\section{Limitations of the Study}

This research has following limitations:

- This study covered only a few commercial banks so inferences drawn from this study may not be directly applicable to all banks and financial institutions of Nepal;

- Banks and their employees does not easily provide the data required for this study and hence the data is collected on personal capacity;

- Time was also one of the limitation;

- The classification of the positions in all banks might not be uniform and hence position-wise findings may not be valid;

- $\quad$ This research needed approval from the HR department to conduct the study. So, the survey might not have received the exact answer from the employees as it was formally approved by the department;

- The study has geographic limitation as the survey was conducted only on selected branches of selected banks inside Kathmandu valley.

\section{REVIEW OF LITERATURE}

\section{Overview of Previous Research}

Employers need to keep the employees from leaving the organization in a short duration for the success of the venture. Employers want their employees to build up a lifelong relationship with the organization, contribute to the performance and success of the firm and become the force behind the growth in long term. But modest aim generally ends with sorrow. Attrition is one of the most puzzling words in the management literature today. It is because the cause and effect relationship here is not absolute. Here, cause and effect relationship is affected by multiple variables and it is difficult to build an empirical or conceptual model on the basis of experience and data. The saying, good help is hard to find, is even true these days because the job market is becoming increasingly tight (Eskildesen, 2000; Hammer, 2000). Employers find it hard to get skilled employees to maintain the prosperity of their organizations (Eskildsen and Nussler, 2000). Employee satisfaction and customer satisfaction varies proportionately (Parrott, 2000). Growing competitiveness in the market provides pressure on the employees. These pressures generally give birth to mental agony to the employees. Parrott (2000) was of the view that today's employees pose a complete new set of challenges. As a result, tapping of talent becomes more complex.

Employees that are satisfied and happy with their jobs are more dedicated and functional in customer service and business operation (Hammer, 2000; Denton, 2000). Also it is proved that employees who are satisfied with their jobs are more productive, creative, and more likely to be retained by the company (Eskildsen and Dahlgaad, 2000; Kim, 2000; Kirby, 2000; Lee, 2000; Wagner, 2000). Again researches have proved that many environmental factors play significant role in the job-switching behavior of the employees such as pay and benefits, communication, motivation, etc. The key organizational (HR) issue being faced today by all the banking sector is attrition. Career growth, compensation and supervision are some 
of the pronounced reasons contributing to attrition. Due to monotonous nature of the job, employees change their jobs frequently. Many companies feel that exit interview is the best way to control or manage attrition rate. No organization can survive without giving importance to its employees. They are the first customers and their requirements should be identified and fulfilled. Like CRM, Employee Relationship Management (ERM) is the mantra an organization should follow to retain their employees. Fulfilling the reasonable expectations of employees should be a continuous process (Anantharaja, 2009).

Industrial attrition literature revealed some factors that affect the attrition which include employee turnover, commitment, motivation, changes in work place, training and development, etc. These finding are valid for the employees who stay in the organization for a long time.

Similarly, one of the case studies on employee attrition in engineering firms in India revealed that attrition was due to the lack of growth and career advancement opportunities (Banerjee, 2010). Aon Hewitt's global employee engagement research in 2011 illustrate that employers will be challenged to attract and retain critical talent to grow their businesses, while at the same time they will continue to face enormous pressure to hold down costs. The overall global average employee engagement score dropped to $56 \%$ in 2010 from $60 \%$ the previous year. The 2010 engagement levels represented the largest decline in employee engagement research that Aon-Hewitt has seen in the last 15 years. By examining employee engagement data, Aon-Hewitt can provide employers a road map and have them focus their efforts on the top drivers that motivate employees. Employers can set themselves up for continued success by focusing on the key engagement drivers that make a positive impact on their workforces and thus keep their employees engaged. Top three engagement drivers are career opportunities, brand alignment, and recognition (Aon-Hewitt, 2011)

\section{Research Gap}

It is difficult to define all the possible reasons and the most promising reasons for attrition in the banks. This research is first of its kind in studying the banking sector from attrition management point of view, especially in the Nepalese context. There has not been research of this kind in the banking sector of Nepal. Researches of this kind are very important to reflect the exact condition of attrition and related factors causing attrition in the banks. There is a very big gap and hence a scope for research in this sector.

\section{Theoretical Framework}

The theoretical framework has been crafted by categorizing all the possible attributes linked with attrition into five broad factors (Figure 1). The attributes in each factor is mentioned below. 


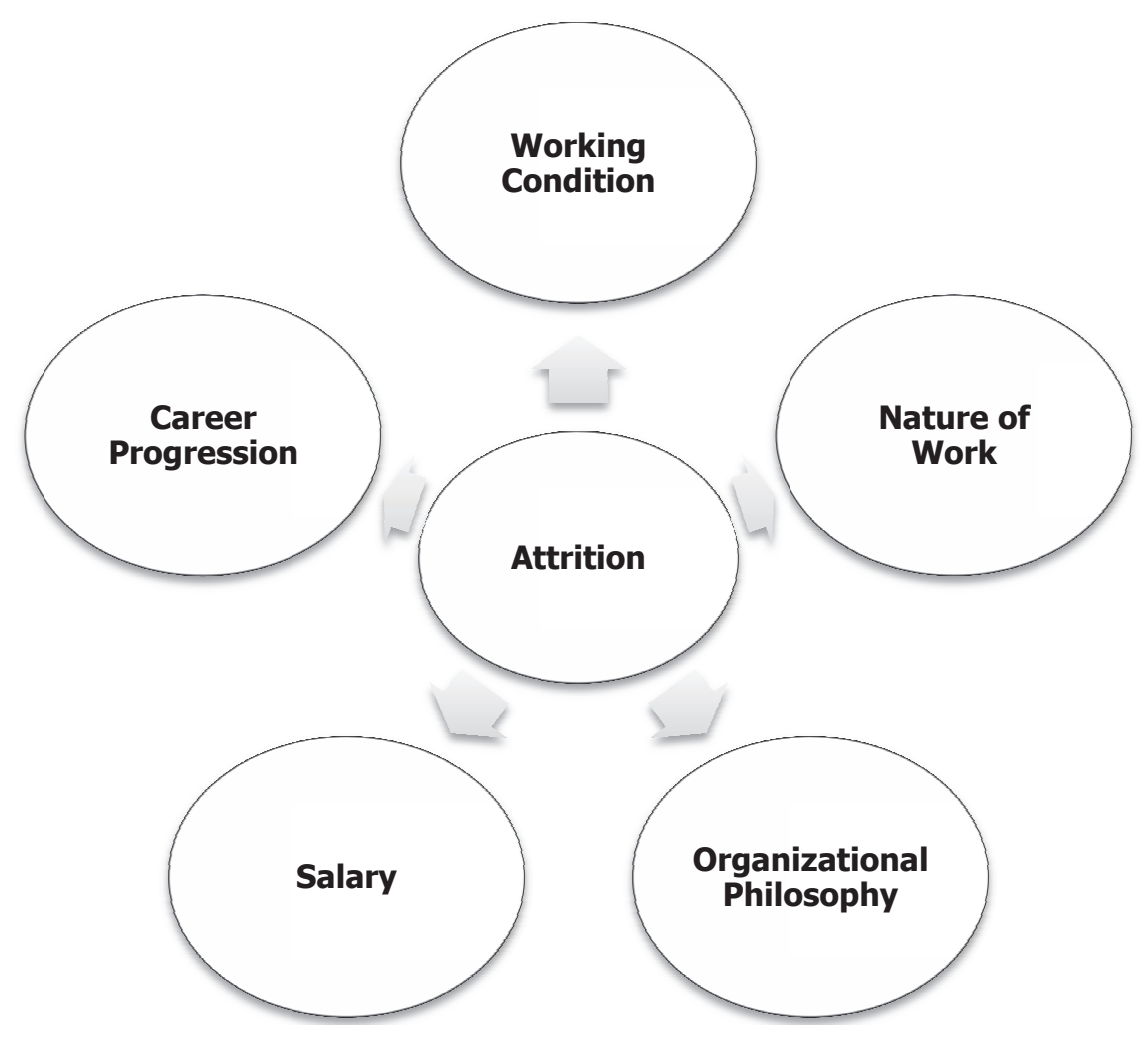

Figure 1: The Theoretical Framework

Factor 1: Working Condition

Job security, Job satisfaction, Flexible working hours, Availability of resources, Working environment, Discrimination, Job roles

Factor 2: Nature of Work

Pressure from supervisor, High pressure of work, Monotonous job, Vague targets, Undistinguishable responsibility, Multiple bosses, Approachable supervisor

Factor 3: Organizational Philosophy

Cooperative peers, Feedback mechanism, Lack of recognition, Motivation, Incentives

Factor 4: Salary

Remuneration at par with other company

Factor 5: Career Progression

Scope for career growth, Scope for skill development

After identifying the factors, effort will be used to find out the most important factors that are actually leading to attrition in banking sector. 


\section{RESEARCH DESIGN AND METHODOLOGY Research Design}

The main aim of the research design is to ensure that the required data are collected objectively, accurately, and economically. A detailed planning was done before commencing the research. Various tools and processes were used as an initial plan of this research. The following factors are especially considered:

- Sample size and selection of sample

- Questionnaires and interviews

- Method of data collection

- Time frame of the research

- Tools to be used in interpreting the findings

- Reliability of study and findings

- Analysis plan

The data used in this research were both quantitative and qualitative in nature. On the basis of the questionnaire and interviews the data were collected and those data were analyzed by constructing a statistical model in an attempt to explain what has been observed regarding causes of attrition in senior level employees of the bank.

\section{Population, Sampling, and Timeframe}

Purposive sampling is used to identify the banks to choose respondents for this research. The scope of the study was limited to the senior level employees (above "Junior Officer" level) of different banks. There are thirty two commercial banks, among which sample was proportionately selected using convenience sampling method based upon availability of data from banks. A total of ten banks were sampled for this research. Responses have been collected from one hundred and two senior level employees currently working in different branches of commercial banks inside the Kathmandu valley. Semi-structured questionnaires (Annex A) were used to conduct the survey. The types of questions asked in the questionnaire were closed-ended, open-ended, likert-scale questions, and multiple choices. Both the primary and secondary data were used in this research. The source of the primary data was the structured questionnaires and interviews with the employees of the selected banks. The source of the secondary data was journals, articles, websites, and other such secondary sources. Time frame for this research was around 2-3 months (from May to July, 2013).

\section{Validity and Reliability}

To test the validity and veracity of the structure of the questionnaire and to find out whether the purpose was fulfilled, a pilot study was conducted where a sample of 20 responses were collected to find opinions of employees about the causes of attrition in their bank. The main objective of using this technique is to understand the current process of the bank and whether the employees were satisfied. The set of Likert-scale questions in the questionnaire were also tested for reliability with Cronbach's Alpha Test. 


\section{Analysis Plan}

After the data was collected it was calculated by using mathematical tools and the result is presented in graphs, charts, tables for the clear understanding of the reader. The conclusion is drawn from the findings from the analysis of this research and recommendation is also made.

For the analysis, SPSS software is used. The responses collected from the respondents was coded and entered into SPSS worksheet. After the coding, the appropriate analyses were done. Averages, measures of central tendency, and measures of dispersion were used in this study to describe the datasets. Various tools like Cross tabulation, correlation, mean, frequency, and other statistical analysis were carried out to draw the inferences from the collected responses. Unidimensional analysis, bi-variate analysis, and multivariate analysis was done to represent descriptive statistics.

\section{RESULTS AND INTERPRETATIONS}

This section has been divided into five parts for analyzing the data collected for the study. The five parts are as under:

- Data sample information

- Multiple responses

- Correlation analysis

- Regression analysis

- Coefficient and hypothesis testing

\section{Data Sample Information}

\section{A. Reliability of the scale}

Cronbach's alpha is a statistics used to determine the internal consistency. The Cronbach's alpha increases as the inter-correlations among the items included in the analysis increase. Table (1) shows the reliability of the total items. The computed Cronbach's alpha is 0.848 , which shows that it is significant and hence reliable for use.

Table 1: Reliability Statistics for Total Items

Table (2) shows the reliability of individual items. Working condition, nature of work, organizational philosophy, and career progression are reliable and shows its significance as the computed alpha value is near to 0.70 , since alpha above 0.70 is considered reliable. 
Table 2: Reliability of Individual Items

\begin{tabular}{lrr}
\hline Variables & Cronbach's Alpha & No. of Items \\
\hline Working Condition & 0.68 & 8 \\
Nature of Work & 0.61 & 9 \\
Organizational Philosophy & 0.73 & 5 \\
Salary & 0.16 & 3 \\
Career Progression & 0.73 & 2 \\
\hline
\end{tabular}

\section{B. Respondents in the Senior Level Position}

Figure (2) represents the percentage distribution of job positions of the employees selected for the survey. About $25.50 \%$ of respondents were Junior Officers (JO), $21.60 \%$ were Officers (OF), $19.60 \%$ were Senior Officers (SO), $20.60 \%$ were Deputy Managers (DM), $7.80 \%$ were Managers (MG), and only $4.90 \%$ of the respondents were Senior Managers (SM) or above.

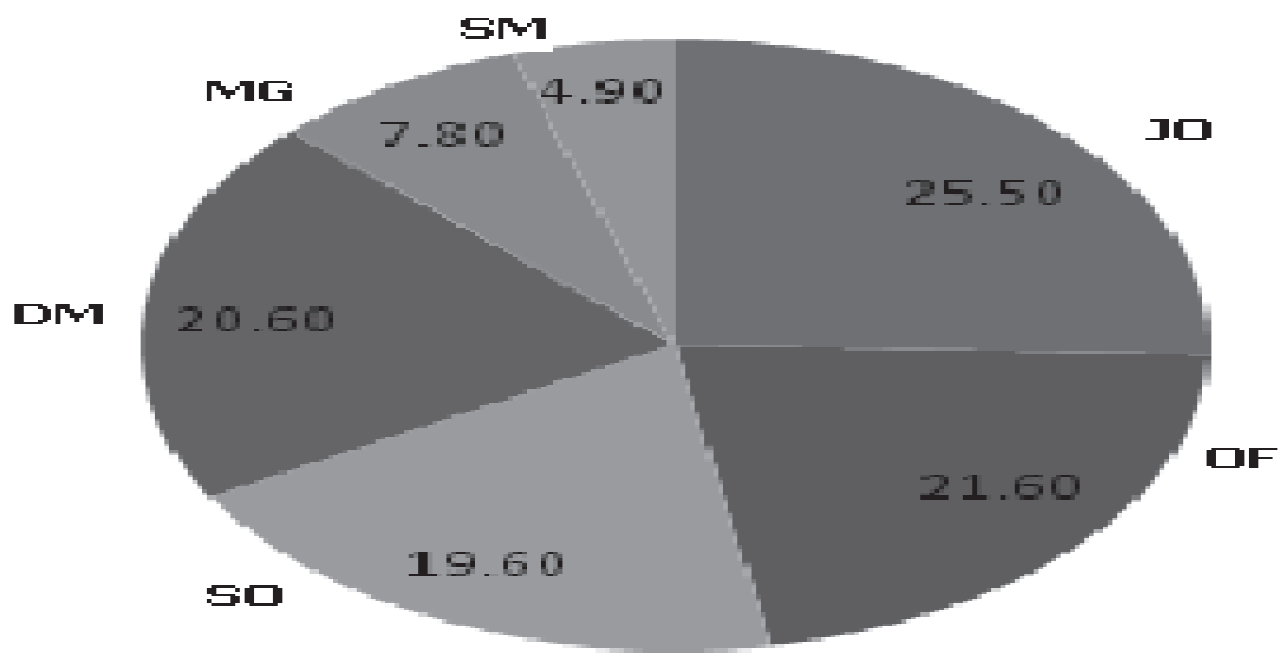

Figure 2: Job Positions of Selected Samples

C. Mean number of years of the respondents working in the current bank and previous bank

Table (3) shows the average years of work of the selected employees in their respective banks. The mean number of years of the employees working in the current bank is around three and half years and the mean number of years of the employees worked in the previous bank is around four and half years.

Table 3: Comparison of respondents working in current Vs previous bank Years worked in current bank Years worked in previous bank

\begin{tabular}{lll} 
Mean & 3.60 & 4.51 \\
\hline
\end{tabular}

From this above table we can understand that the average number of years is four and half in the senior level position where the employees make a switch to another bank. 


\section{Multiple Responses}

\section{A. Ranking of the factors those are important in workplace}

Table (4) shows the ranking of the factors important in the workplace for the selected employees. The respondents ranked career growth or skill development as first priority, job security as second priority, and good remuneration as only the third priority. Job rotation, flexible work hours, and effective feedback mechanism were of less importance to the senior level employees of the commercial banks.

Table 4: Ranking of the factors important in workplace

\begin{tabular}{lrr}
\hline Rank of Factors Important in Workplace & Responses & Percent \\
\hline Career Growth or Skill Development & 42 & 41.18 \\
Job Security & 21 & 20.59 \\
Good Remuneration & 15 & 14.71 \\
Motivation & 10 & 9.80 \\
Cooperative Supervisors & 6 & 5.88 \\
Job Rotation & 3 & 2.94 \\
Flexible Work Hours & 3 & 2.94 \\
Feedback Mechanism & 2 & 1.96 \\
\hline Total & 102 & 100.00 \\
\hline
\end{tabular}

Dichotomy group tabulated at value 1

Thus, we should understand that there should be trainings, policies and procedures that focus on career growth, skill development, Job security, as well as good remuneration.

\section{B. Percentage distribution on factors those were missing in previous job}

Table (5) shows the responses collected from the respondents regarding the factors that were missing in the previous job and that may be the main reason for leaving that job. The multiple choice question received highest of $21.61 \%$ responses for scope of career growth as the factor that was missing in the previous bank. Thus, it seems that the employee will leave the job if $s /$ he could not see career growth perspective in his/her organization. The second and third factors that were missing were recognition and job satisfaction, with $12.09 \%$ and $11.72 \%$ of responses, respectively. It seems that job security and teamwork is valued less and hence the responses for good supervisor and cooperative team-members are found to be low. 
Table 5: Distribution on factors those were missing in the Previous Job

\begin{tabular}{lrr}
\hline Factors Missing in the Previous Job & Responses & Percent \\
\hline Scope of Career Growth & 59 & 21.61 \\
Recognition & 33 & 12.09 \\
Job Satisfaction & 32 & 11.72 \\
Motivation Incentives & 26 & 9.52 \\
Working Environment & 24 & 8.79 \\
Remuneration & 22 & 8.06 \\
Feedback Mechanism & 19 & 6.96 \\
Flexible Work Hours & 16 & 5.86 \\
Scope of Skill Development & 15 & 5.49 \\
Approachable Supervisor & 11 & 4.03 \\
Job Security & 9 & 3.30 \\
Cooperative Peers & 7 & 2.56 \\
\hline Dichotomy group tabulated at value 1 & \multicolumn{2}{c}{}
\end{tabular}

C. Percentage distribution on factors those were missing in Current Job

Table (6) shows the responses collected from the respondents regarding the factors currently missing in the jobs of bank employees. The multiple choice question received highest of $16.28 \%$ responses and second highest of $12.79 \%$ responses for remuneration and motivational incentives respectively as the factors that were missing in the current bank. The third factor was feedback mechanism with $10.85 \%$ of total responses.

Table 6: Distribution on factors those were missing in the current job

\begin{tabular}{lrr}
\hline Factors Missing in the Current Job & Responses & Percent \\
\hline Remuneration & 42 & 16.28 \\
Motivation Incentives & 33 & 12.79 \\
Feedback Mechanism & 28 & 10.85 \\
Scope of Skill Development & 24 & 9.30 \\
Flexible Work Hours & 24 & 9.30 \\
Scope of Career Growth & 21 & 8.14 \\
Recognition & 20 & 7.75 \\
Job Satisfaction & 18 & 6.98 \\
Approachable Supervisor & 16 & 6.20 \\
Working Environment & 16 & 6.20 \\
Cooperative Peers & 9 & 3.49 \\
Job Security & 7 & 2.71 \\
\hline
\end{tabular}

Dichotomy group tabulated at value 1 


\section{Percentage distribution on reason to leave the last job}

Table (7) shows the responses collected from the respondents for the reason leaving the last job. The multiple choice question received highest of $22.08 \%$ responses for no scope for career growth and second highest of $12.50 \%$ responses for lack of recognition, as the factors that led them to switch the job. The third factor was lack of motivation with $10.42 \%$ of total responses.

Table 7: Percentage distribution on Reason for leaving the last job

\begin{tabular}{lrr}
\hline Reason for leaving the last job & Responses & Percent \\
\hline No scope for Career Growth & 53 & 22.08 \\
Lack of Recognition & 30 & 12.50 \\
Lack of Motivation & 25 & 10.42 \\
Monotonous Job & 22 & 9.17 \\
Less Remuneration & 22 & 9.17 \\
No scope for Skill Development & 21 & 8.75 \\
Unclear Job Roles & 16 & 6.67 \\
No/Low Incentives & 15 & 6.25 \\
Discrimination & 14 & 5.83 \\
Multiple Bosses & 8 & 3.33 \\
High Pressure of Work & 8 & 3.33 \\
Pressure from Supervisor & 6 & 2.50 \\
\hline
\end{tabular}

Dichotomy group tabulated at value 1

\section{Correlation Analysis}

Correlation analysis showed that there is a degree of association between natures of work and working condition, organizational philosophy, career progression, that is, $36 \%, 35 \%$, and $33 \%$ respectively (Table 8 ) and also shows low probability of error. There is a degree of association between organizational philosophy and career progression $(31 \%)$. However, it has been found that the working condition has no association with salary and organizational philosophy. 
Table 8: Correlations

\begin{tabular}{llrrrrr}
\hline & & WC & NW & OP & SY & CP \\
\hline Working & PC & 1 & - & - & - & - \\
Condition (WC) & Sig. (2-tailed) & - & - & - & - & - \\
Nature of Work & PC & $* * 0.36$ & 1 & - & - & - \\
(NW) & Sig. (2-tailed) & 0.00 & - & - & - & - \\
Organizational & PC & 0.18 & $* * 0.36$ & 1 & - & - \\
Philosophy (OP) & Sig. (2-tailed) & 0.06 & 0.00 & - & - & - \\
Salary (SY) & PC & 0.12 & 0.15 & -0.02 & 1 & - \\
& Sig. (2-tailed) & 0.22 & 0.14 & 0.81 & - & - \\
Career & PC & $* * 0.34$ & $* * 0.33$ & $0.31 * *$ & 0.13 & 1 \\
Progression (CP) & Sig. (2-tailed) & 0.00 & 0.00 & 0.00 & 0.19 & - \\
\hline
\end{tabular}

PC $=$ Pearson Correlation; Sig. = significance; $* *$ Correlation is significant at the 0.01 level

\section{Regression Analysis}

It includes Model Summary, ANOVA, and Coefficient.

Model summary is shown in Table (9). Value of $\mathrm{R}$ Square is 0.26 , which shows that around $26 \%$ variation in attrition of senior level employees are due to the independent variables working condition, nature of work, organizational philosophy, salary and career progression.

Table 9: Model Summary

\begin{tabular}{lrrrr}
\hline Model & $\mathbf{R}$ & R-Square & Adjusted $\mathbf{R}^{\mathbf{2}}$ & SE \\
\hline 1 & 0.51 & 0.26 & 0.22 & 1.30 \\
\hline
\end{tabular}

Predictors: (Constant), Career Progression, Salary, Nature of Work, Working Condition, Organizational Philosophy; SE = Standard Error

F-statistics analysis was carried out to find the overall strength of the model. The value of F-Statistic is 6.69 (Table 10), which shows that the model is highly significant.

Table 10: ANOVA

\begin{tabular}{lrrrrr}
\hline Model & Sum of Squares & D.f. & Mean Square & \multicolumn{1}{c}{ F } & Significance \\
\hline 1 Regression & 56.67 & 5 & 11.33 & 6.69 & 0.00 \\
Residual & 162.59 & 96 & 1.69 & - & - \\
Total & 219.26 & 101 & - & - & -
\end{tabular}

Predictors: (Constant), Career Progression, Salary, Nature of Work, Working Condition, Organizational Philosophy; D.f. = degree of freedom;

On the basis of Beta coefficients the model shows that working condition causes $39 \%$ positive variation in attrition in senior level employees and $t$-value is also significant. So we accept first hypothesis, which states that there is significant relationship between working condition and attrition. Nature of work causes $58 \%$ variation in attrition in senior level employees in positive direction. Here t-value is 
also significant. So we accept the hypothesis that there is significant relationship between nature of work and attrition. Organizational philosophy causes $80 \%$ variation in attrition in senior level position but in negative direction and $t-$ value is also insignificant. So we could not accept the hypothesis that there is significant relationship between organizational philosophy and attrition. Salary causes 35\% variation in attrition in senior level position but in negative direction and $t-$ value is also insignificant. So, again we could not accept the hypothesis that there is significant relationship between salary and attrition. Career progression causes 37\% variation in attrition in senior level position but in negative direction and $t-$ value is also insignificant. So, in this case also we could not accept the hypothesis that there is significant relationship between career progression and attrition.

Table 11: Coefficients ${ }^{\text {a }}$

\begin{tabular}{|c|c|c|c|c|c|}
\hline \multirow[t]{2}{*}{ Model } & \multicolumn{2}{|c|}{ Un-standardized } & \multirow{2}{*}{$\begin{array}{r}\text { Standardized } \\
\text { Beta }\end{array}$} & \multirow[t]{2}{*}{ t-Value } & \multirow{2}{*}{$\begin{array}{r}\text { Significanc } \\
\text { e }\end{array}$} \\
\hline & Beta & SE & & & \\
\hline 1 (Constant) & 4.04 & 0.66 & - & 6.19 & 0.00 \\
\hline Working Condition & 0.39 & 0.17 & 0.25 & 2.27 & 0.03 \\
\hline Nature of Work & 0.58 & 0.18 & 0.34 & 3.23 & 0.00 \\
\hline Org. Philosophy & -0.80 & 0.17 & -0.53 & -4.70 & 0.00 \\
\hline Salary & -0.35 & 0.15 & -0.22 & -2.33 & 0.02 \\
\hline Career Progression & -0.37 & 0.16 & -0.22 & -2.24 & 0.03 \\
\hline
\end{tabular}

${ }^{\mathrm{a}}$ Dependent Variable: Current Position in Bank; SE = Standard Error; Org. = Organizational

\section{CONCLUSIONS AND RECOMMENDATIONS Conclusion}

This study was conducted to explore the important factors that cause attrition in senior level position of commercial banks. Research was conducted on commercial bank branches inside Kathmandu Valley. Several hypotheses are made to check the effect of independent variables on dependent variables. By using the appropriate statistical package it is found that working condition, nature of work, organizational philosophy, salary, and career progression are the factors that causes attrition to some level. Two hypotheses are accepted and three hypotheses are rejected.

Working condition and nature of work shows the positive association on attrition and the significance level is also high. Organizational philosophy, salary, and career progression has a negative association on attrition but these were insignificant. Since, the study was done in senior level position of commercial bank, this result can infer that there is not much association of salary, organizational philosophy, and career progression with attrition at this level. However, this result should be taken with precaution, since it is a preliminary research of this kind and since the responses are subject to approval by the HR department.

The respondents ranked career growth or skill development as first, job security as second and good remuneration as third factor important in a workplace. Scope of career growth, recognition, and job satisfaction were the top three factors that were missing in the previous bank. It was also found that remuneration, 
motivational incentives, and feedback mechanism are missing in the current job with total of almost $40 \%$ responses for these three factors.

From this we can infer that there should be trainings, policies, and procedures that focus on career growth, skill development, job security, as well as handsome remuneration for staff retention. Motivational incentives, feedback mechanism, and skill development should also not be completely ignored from the HR plans and policies.

Senior level employees have made a switch due to no scope for career growth, lack of recognition, and lack of motivation. These factors were the top three reasons for them to make a switch with $45 \%$ of total responses to these three factors out of twelve. Therefore, it could be said that in the senior level position, it is the intrinsic factors that causes attrition in bank. So, there has to be correct measures that focus on intrinsic factors while making policies and procedures for senior level employees.

\section{Suggestions and Recommendations}

The HR department of all the banks and financial should carry out these types of researches frequently within their bank to understand the exact factors that are causing attrition. The HR policies and organizational philosophy should reflect the factors that has high ranking in this kind of research. Career growth, skill development activities, job security, and remuneration are the factors that need to be considered well in the HR designs. Lack of motivation, lack of recognition and no scope of career growth are the factors that are leading employees to switch banks. There has to be trainings and workshops to improve these factors and help recover the attrition rate. Banks should be open for any kind of research that will help them identify a problem and have correct measures to solve the problem. The perception of bankers should also change and they should come out of their daily routine job to help researchers for mutual benefit. There were very few banks aware of the attrition rate of their banks. But, unfortunately it was limited to recording of the statistics. Newer commercial banks were approachable than old ones. The reactions of the newer banks were positive but it was very difficult to approach older commercial banks. It would have been much easier for the research if the older banks were open to this kind of research, which is one of the major shortcomings of this research.

\section{ACKNOWLEDGEMENT}

This research has been partially funded by the Nepal Bankers' Association, Banking Promotion Committee Research Grant, RG\#2(A).

\section{REFERENCES}

Anantharaja, A. 2009. Causes of attrition in BPO companies: Study of a mid-size organization in India. IUP Journal of Management Research, 8 (11): Pp. 1327.

Aon-Hewitt. 2011. Trends in Global Employee Engagement. Talent and Organization. Aon-Hewitt, London, England. 
Banerjee, S. 2010. Employee Attrition in Engineering Firms: Case Study of DCIPS Pvt. Ltd, India. Proceedings of the 2010 International Conference on Industrial Engineering and Operations Management, held from January 910, 2010, at Dhaka, Bangladesh.

Denton, K. 2000. I hate this job! Business Horizons, 7 (1): Pp. 46-52.

Eskildsen, J. K. and J. J. Dahlgaard. 2000. A Casual Model for Employee Satisfaction. Total Quality Management, 11 (8): Pp. 1081-1095.

Eskildsen, J. K. and M. L. Nussler. 2000. The managerial drivers of employee satisfaction and loyalty. Total Quality Management, 11 (4): Pp. 581-588.

Hammer, R. 2000. Winning program brings smiles to hotel's employees. Houston Business Journal, 43 (A): Pp. 245-93.

Kim, J. 2000. Does attitude toward money moderate the relationship between intrinsic job satisfaction and voluntary turnover? Human Relations, 52 (2): Pp. 213-45.

Kirby, S. 2000. Impact of Marketing Work-Place Diversity on Employee Job Involvement and Organizational Commitment. Journal of Social Psychology, 140 (3): Pp. 367-77.

Lee, C. 1999. The Importance of Justice Perceptions on Pay Effectiveness: A TwoYear Study of a Skill-Based Pay Plan. Journal of Management, 25 (6): Pp. 851-73.

Parrott, M. 2000. Employee Satisfaction. Do-It-Yourself Retailing 15 (8): Pp. 493522.

Wagner, S. 2000. Retention: Finders, Keepers. Training and Development, 54 (8): Pp. 64. 


\section{ANNEXES}

\section{Annex 1: Questionnaire}

\section{Questionnaire for Employee Attrition Survey of Senior Level Employees from Selected Commercial Banks \\ (Note: If you have not worked for two or more than two banks then you should not be filling up this questionnaire)}

Q1. Please select your current position:

$\begin{array}{lll}\text { Junior Officer } & \text { Officer } & \text { Senior Officer } \\ \text { Deputy Manager } & \text { Manager } & \text { Senior Manager }\end{array}$

If you do not fall within these above positions, please end the questionnaire.

Q2. Please mention the number of years you have worked for in your current office.

Q3. Please mention the number of years you have worked for in your previous office.

Q4. Please rank these options from 1 to 8 which according to you are most important in a workplace.

Job Security

Flexible Work Hours

Cooperative Supervisors

Feedback Mechanism

Good Remuneration

Career Growth / Skill Development

Motivation

Job Rotation

Q5. Please select the factors that were missing in your previous job.

(You may select more than one factor)

Job security Job satisfaction

Working environment Approachable supervisor

Cooperative peers

Feedback mechanism

Recognition

Motivation / Incentives

Scope for career growth

Scope for skill development

Remuneration at par with other company

Q6. Please select the factors that are missing in your current job.

(You may select more than one factor)

Job security

Working environment

Cooperative peers

Recognition

Scope for career growth

Remuneration at par with other company

Q7. Please select the options that closely match the reason why you left your last job.

(You may select more than one factor)

Job security

Working environment

Cooperative peers

Recognition

Job satisfaction

Approachable supervisor

Feedback mechanism

Motivation / Incentives

Scope for skill development

Flexible working hours

Scope for career growth

Remuneration at par with other company
Approachable supervisor

Feedback mechanism

Motivation / Incentives

Scope for skill development 


\section{Please rank between "Strongly Agree - Agree - Neutral - Disagree - Strongly Disagree" for the questions below (Q8 - Q34):}

\section{Working Condition}

Q8. I love to work at this office.

Q9. I wish there was other working shifts.

Q10. I have a clear sense of the future direction in this office.

Q11. The atmosphere of this office is friendly.

Q12. This office has policies that support its staff.

Q13. There are leaders in this office I can trust.

Q14. Others in this office trust me to perform my job.

Q15. Communication between staff and this office's upper leadership is effective.

\section{Nature of Work}

Q16. My supervisor understands me and appreciates my work.

Q17. My workload and expected completion times are reasonable.

Q18. The workload in this office is distributed equitably.

Q19. There are sufficient roles for staff to avoid job monotony.

Q20. I have a clear understanding of how my job performance is measured.

Q21. I receive constructive feedback about the quality of my work.

Q22. I know exactly what is expected of me as an employee.

Q23. This office has regular staff meetings to plan and coordinate work and to make announcements.

Q24. I feel I am heard, when I communicate with others in my office.

\section{Organizational Philosophy}

Q25. I received a thorough orientation to this office and my job when I started.

Q26. There is a spirit of cooperation among staff in this office.

Q27. There are good incentives for staff in this office.

Q28. Conflict among staff in my office is managed effectively

Q29. Promoting respect and fair treatment among all staff is a high priority of this office.

\section{Salary}

Q30. I am satisfied with my pay scale in this office.

Q31. I know I can get more in other office for same level of work.

Q32. I value my work more than salary.

\section{Career Progression}

Q33. There are lots of skill development opportunities in this office.

Q34. This office has scope for career growth. 


\section{Annex 2: Descriptive Statistics}

\begin{tabular}{lllll}
\hline Working Condition & N & Sum & Mean \\
\hline Q8 & I love to work at this office. & 102 & 224 & 2.20 \\
Q9 & I wish there was other working shifts. & 102 & 320 & 3.14 \\
& I have a clear sense of the future direction in this & & & \\
Q10 & office. & 102 & 250 & 2.45 \\
Q11 & The atmosphere of this office is friendly. & 102 & 221 & 2.17 \\
Q12 & This office has policies that support its staff. & 102 & 271 & 2.66 \\
Q13 & There are leaders in this office I can trust. & 102 & 251 & 2.46 \\
Q14 & Others in this office trust me to perform my job. & 102 & 215 & 2.11 \\
& Communication between staff and this offices upper & & & \\
Q15 & leadership is effective. & 102 & 260 & 2.55 \\
\hline
\end{tabular}

Cumulative Mean for Working Condition

2.47

\begin{tabular}{|c|c|c|c|c|}
\hline \multicolumn{2}{|c|}{ Nature Of Work } & $\mathbf{N}$ & Sum & Mean \\
\hline Q16 & $\begin{array}{l}\text { My supervisor understands me and appreciates my } \\
\text { work. }\end{array}$ & 102 & 219 & 2.15 \\
\hline Q17 & reasonable. & 102 & 271 & 2.66 \\
\hline Q18 & $\begin{array}{l}\text { The workload in this office is distributed equitably. } \\
\text { There are sufficient roles for staff to avoid job }\end{array}$ & 102 & 278 & 2.73 \\
\hline Q19 & $\begin{array}{l}\text { monotony. } \\
\text { I have a clear understanding of how my job }\end{array}$ & 102 & 274 & 2.69 \\
\hline Q20 & $\begin{array}{l}\text { performance is measured. } \\
\text { I receive constructive feedback about the quality of }\end{array}$ & 102 & 236 & 2.31 \\
\hline Q21 & $\begin{array}{l}\text { my work. } \\
\text { I know exactly what is expected of me as an }\end{array}$ & 102 & 248 & 2.43 \\
\hline Q22 & $\begin{array}{l}\text { employee. } \\
\text { This office has regular staff meetings to plan and }\end{array}$ & 102 & 203 & 1.99 \\
\hline Q23 & $\begin{array}{l}\text { coordinate work and to make announcements. } \\
\text { I feel I am heard, when I communicate with others }\end{array}$ & 102 & 253 & 2.48 \\
\hline Q24 & in my office. & 102 & 243 & 2.38 \\
\hline
\end{tabular}




\begin{tabular}{lllll}
\hline Organizational Philosophy & N & Sum & Mean \\
\hline Q25 & $\begin{array}{l}\text { I received a thorough orientation to this office and } \\
\text { my job when I started. }\end{array}$ & 102 & 280 & 2.75 \\
$\begin{array}{l}\text { There is a spirit of cooperation among staff in this } \\
\text { Q26 }\end{array}$ & 102 & 249 & 2.44 \\
Q27 & $\begin{array}{l}\text { There are good incentives for staff in this office. } \\
\text { Conflict among staff in my office is managed } \\
\text { effectively }\end{array}$ & 102 & 305 & 2.99 \\
Q28 & 102 & 266 & 2.61 \\
Q29 & $\begin{array}{l}\text { Promoting respect and fair treatment among all is a high priority of this office. } \\
\text { staff }\end{array}$ & 102 & 278 & 2.73 \\
\hline
\end{tabular}

\section{Cumulative Mean for Organizational Philosophy}

\begin{tabular}{lllll}
\hline Salary & N & Sum & Mean \\
\hline Q30 I am satisfied with my pay scale in this office. & 102 & 290 & 2.84 \\
& I know I can get more in other office for same level & & & \\
Q31 & 102 & 231 & 2.26 \\
Q32 $\quad$ I value my work more than salary. & 102 & 199 & 1.95 \\
\hline Cumulative Mean for Salary & & & $\mathbf{2 . 3 5}$ \\
\hline
\end{tabular}

\begin{tabular}{llll}
\hline Career Progression & N & Sum & Mean \\
\hline There are lots of skill development opportunities in & & & \\
Q33 & 102 & 262 & 2.57 \\
Q34 $\quad$ This office. & 102 & 240 & 2.35 \\
\hline Cumulative Mean for Career Progression & & & $\mathbf{2 . 4 6}$ \\
\hline
\end{tabular}

